\title{
NILAI KEPUASAN PENGUNJUNG SAUNG ANGKLUNG UDJO
}

\section{Didin Syarifuddin}

Sekolah Tinggi Pariwisata ARS Internasional, Bandung, Indonesia, email: didinars123@ gmail.com

\section{Histori Artikel}

Submitted:

2 Juli 2021

Reviewed:

10 Juli 2021

Accepted:

10 Agustus 2021

Published:

15 November 2021

\section{ABSTRAK}

Pelanggan adalah orang penting dalam organisasi bisnis, tidak bergantung pada perusahaan bukan orang untuk diperdebatkan, sehingga keinginan pelanggan merupakan tugas perusahaan untuk bisa diwujudkan. Tujuan penelitian ini untuk menjelaskan nilai kepuasan pelanggan sebagai dampak dari nilai pelanggan. Penelitian ini menggunakan metode verifikatif dengan analisis regresi. Hasil penelitian menjelaskan bahwa seni pertunjukan Saung Angklung Udjo merupakan pertunjukan seni tradisional yang menghasilkan alunan nada yang indah, dapat menumbuhkan kesenangan dan kepuasan penontonnya, dampak dari tumbuhnya nilai pentas seni, pelayanan, personal, citra dan nilai biaya. Tumbuhnya nilai pengunjung berdampak pada tumbuhnya kepuasan pengunjung sehingga menumbuhkan pengetahuan, rasa senang dan kembalinya rasa gembira masyarakat dari perasaan jenuh karena rutinitas hariannya. Ini merupakan aspek penting dalam masyarakat yang dapat dijadikan acuan dalam proses interaksi serta sebagai pola tingkah laku dan pola fikir kelompok yang diakui bersama dalam melakukan wisata.

Kata Kunci: Pengunjung, Nilai Pengunjung, Kepuasan Pengunjung

\section{TOURIST SATISFACTION VALUE OF SAUNG ANGKLUNG UDJO}

\begin{abstract}
Customers are important people in business organizations, do not depend on the company, not people for debate, so that customer desires are the company's duty to be realized. The study purpose is to explain customer satisfaction value as an impact of implementing customer value. The verification method used to explain the effect of customer value on customer satisfaction with regression analysis. The results explain that Saung Angklung Udjo performance art is a traditional art performance producing beautiful tones, can foster audience enjoyment and satisfaction, the impact of growing value of performing arts, service, personal, image and cost value. The growth in visitor value has an impact on growth of visitor satisfaction so as to foster knowledge, a sense of pleasure and the return of fresh feeling to people who experience boredom from their daily routines. This is an important aspect in society that can be used as a reference in the process of interaction as well as a pattern of behavior and group thought patterns that are mutually recognized in traveling.
\end{abstract}

Keywords: Visitor, Visitor Value, Tourist Satisfaction 


\section{PENDAHULUAN}

Bandung memiliki citra positif dari wisatawannya (Syarifuddin, 2018). Bandung dikenal dengan fashion, food, dan fun yang menjadi bagian penting dalam pariwisata (Syarifuddin, 2017). Bandung dikenal dengan sejuta sajian kuliner yang menarik dan atraksi wisata tradisional yang berkelas Internasional (Syarifuddin, 2018). Bandung memiliki keunikan strategis dengan potensi dan keragaman wisata alam dan wisata budaya (Syarifuddin, 2016). Tingginya tingkat apresiasi masyarakat terhadap Kota Bandung menjadi motivasi bagi Kota Bandung untuk dapat memberikan yang terbaik kepada pengunjungnya. Seni pertunjukan Saung Angklung Udjo merupakan bagian dari upaya Kota Bandung dalam memberikan pelayanan maksimal kepada pengunjung.

Pelanggan adalah raja (Syarifuddin, 2012). Pelanggan adalah investasi jangka panjang bagi perusahaan, sehingga perusahaan harus dapat memberikan pelayanan terbaik kepada pelanggan untuk keberlangsungan bisnisnya melalui penciptaan nilai pelanggan (Jefry Romdhoni, Juju, Jusuf, \& Rosmadi, 2018). Pelanggan adalah asset serta sumber daya penting dalam perusahaan untuk keunggulan kompetitif, karena semakin lama pelanggan tinggal di perusahaan, maka semakin tinggi keuntungan perusahaan (Yulisetiarini \& Prahasta, 2019). Pelanggan adalah orang yang paling penting dalam sebuah organisasi bisnis, tidak bergantung pada perusahaan, justru sebaliknya perusahaan sangat bergantung pada pelanggan. (Kotler, 2009:205). Pentingnya pelanggan memberikan kesimpulan bahwa pelanggan adalah orang yang paling penting yang harus mendapatkan kepuasan dari organisasi bisnis, karena kepuasan pelanggan akan menjadi faktor kunci kesuksesan bisnis di masa depan (Ming Tien Tsai, Tsai, \& Chang, 2010).

Upaya memberikan kepuasan kepada pelanggan dilakukan melalui nilai pelanggan yang merupakan tugas pokok perusahaan, karena nilai pelanggan yang tinggi dapat meningkatkan kepuasan pelanggan (Galih
Ginanjar Saputra \& Juju, 2020). Belanja pelanggan dilakukan atas dasar nilai yang diharapkan kerena akan berdampak pada kepuasan dan loyalitas pelanggan, sehingga berpotensi melakukan pembelian ulang (Ming Tien Tsai, 2010). Memberikan nilai yang luar biasa kepada pelanggan merupakan satu-satunya cara yang dapat diandalkan untuk mencapai kepuasan pelanggan berkelanjutan (Wahyuningsih, 2005). Perusahaan yang dapat memberikan nilai pelanggan yang lebih tinggi dari pesaingnya berpeluang memperoleh keunggulan bersaing, sehingga konsumen akan memilih perusahaan yang dapat memberikan nilai yang tinggi bagi pelanggannya (Logiawan \& Subagio, 2014). Sangat jelas bahwa nilai merupakan variabel penting dalam dunia bisnis yang sangat kompetitif saat ini dan menjadi aspek yang paling mendasar dalam kegiatan pemasaran serta menjadi faktor kunci dalam manajemen strategis (Halimatussakdiah, Mirza, Irma 2009). Nilai pelanggan memainkan peran penting dalam meningkatkan pembelian kembali pelanggan (Vivi I. Nursyirwan, Valentika, 2020). Menawarkan nilai pelanggan merupakan perhatian berkelanjutan dari manajemen di banyak pasar bisnis, karena nilai yang ditawarkan berpengaruh signifikan terhadap kepuasan pelanggan (Tran Van Dat \& Nhat Minh, 2020). Konsumen menuntut nilai yang lebih tinggi dari layanan yang diterimanya dibandingkan dengan biaya konsumen (Supriyadi, Hertanto, \& Rafiq, 2020). Artinya nilai merupakan aspek penting bagi pelanggan. Berbicara konsep nilai pelanggan akan memperhitungkan perspektif apa yang diinginkan dan diyakini pelanggan (Sambinelli \& Francisco Borges, 2019). Ketercapaian nilai pelanggan, akan mendapatkan kepuasan pelanggan dan menjadi fokus perusahaan.

Saung Angklung Udjo adalah destinasi pariwisata dengan seni pertunjukan Angklung (Syarifuddin, 2018). Angklung merupakan jenis kesenian yang berkaitan dengan budaya Sunda. Saung Angklung Udjo dikenal di dunia Internasional (Syarifuddin, 
2018). Tingginya tingkat popularitas seni pertunjukan Saung Angklung Udjo, tidak menjadikan destinasi pariwisata ini tetap diminati oleh banyak pengunjung, namun penurunan nilai pelanggan diduga sebagai faktor penentu penurunan tingkat kunjungan.

Berdasarkan latar belakang masalah di atas, maka rumusan masalah yang disampaikan adalah bagaimana dampak nilai pengunjung terhadap kepuasan pengunjung di Saung Angklung Udjo. Atas dasar rumusan masalah tersebut maka tujuan penelitian ini adalah untuk mengetahui lebih mendalam tentang dampak nilai pengunjung terhadap kepuasan pengunjung dan bagaimana memberikan makna terhadap nilai kepuasan pengunjung sebagai aspek penting dalam destinasi pariwisata sebagai dampak dari nilai pengunjung di Saung Angklung Udjo. Atas dasar rumusan masalah serta tujuan penelitian ini maka penulis menentukan tema penelitian kepuasan pengunjung dampak dari nilai pengunjung Saung Angklung Udjo.

\section{LITERATUR REVIEW}

Nilai pelanggan didasarkan pada perspektif pelanggan dengan mempertimbangkan apa yang mereka inginkan dan membandingkannya dengan apa yang mereka dapatkan dari penggunaan produk yang dibeli (Tjiptono, 2014:308). Nilai pelanggan merupakan keseluruhan penilaian konsumen tentang kegunaan suatu produk yang didasarkan pada persepsi tentang apa yang diterima dan apa yang diberikan (Zeithaml, 1988). Nilai pelanggan berupa pelayanan yang diberikan perusahaan serta manfaat produk, sedangkan pelanggan mengeluarkan uang, waktu, fisik dan tenaga guna mendapatkan suatu produk atau jasa (Rangkuti, 2006). Nilai pelanggan adalah selisih antara jumlah nilai pelanggan dan jumlah biaya pelanggan. (Kotler \& Keller, 2009:49). Nilai pelayanan tidak ditentukan oleh harga, melainkan manfaat yang pembeli dapatkan ketika mengkonsumsi produk (Lupiyoadi \& Ramdhani, 2011:98). "Value is a ratio between what the customer gets and what the customer gives. The customer gets benefits and assumes costs. Benefits are cost, energy cost, physical cost. Satisfaction is a person's feeling of pleasure and disappointment resulting from comparing a product' $s$ perceived performance (or outcome) in relation to his or her expectation" (Kotler dan Amstrong, 2008:201).

Nilai pelanggan adalah nilai total yang diperoleh pelanggan dari manfaat berupa nilai produk, nilai pelayanan, nilai citra, nilai personal serta nilai biaya yang dirasakan setelah mengkonsumsi barang atau jasa dan membandingkannya dengan biaya berupa uang, waktu, energi serta biaya fisik yang dikeluarkannya. Nilai pelanggan dibangun dari hasil perbandingan antara manfaat fungsional dan manfaat emosional yang diterima pelanggan dengan biaya berupa uang, waktu, energi dan fisik.

Nilai pelanggan dapat diukur dengan menggunakan emotional value; social value, performance value, dan value of money. (Tjiptono, 2014). Sementara Kotler dan Keller (2009) mengemukakan dimensi nilai pelanggan, yaitu nilai produk, nilai pelayanan, nilai personil, nilai citra dan nilai biaya.

Kepuasan adalah perasaan senang atau kecewa seseorang yang timbul karena membandingkan kinerja yang dipersepsikan produk terhadap ekspektasi pelanggan (Kotler dan Keller, 2009:139). Gasperz (2011:38) menjelaskan bahwa kepuasan pelanggan merupakan suatu keadaan dimana kebutuhan dan harapan pelanggan terpenuhi melalui produk yang dikonsumsi, sehingga kepuasan dan ketidakpuasan merupakan perbandingan antara harapan pelanggan dan kenyataan dari kualitas produk dan pelayanan yang dirasakan oleh pelanggan. Pelanggan yang puas biasanya tetap setia terhadap produk yang dikonsumsinya untuk waktu yang lebih lama, membeli lagi ketika perusahaan memperkenalkan produk baru, membicarakan hal-hal baik tentang perusahaan dan produknya kepada orang 
lain. Pelanggan yang puas juga tidak akan memperhatikan merek pesaing dan tidak terlalu sensitif terhadap harga (Kotler \& Keller, 2009:140). Tingkat kepuasan pelanggan dapat meningkatkan loyalitas pelanggan dan mencegah perputaran pelanggan, mengurangi sensivitas pelanggan terhadap harga, mengurangi biaya kegagalan pemasaran, meningkatkan efektivitas iklan dan meningkatkan reputasi bisnis (Lupiyoadi dan Hamdani, 2011:192). Ada tiga aspek dalam mengukur kepuasan (Fornell et all, 1996) yaitu overall satisfaction, confirm to expectation, dan comparison to ideal.

Dalam menentukan kepuasan, seorang pelanggan melihat nilai produk maupun kinerja pelayanan yang diterima dari proses pembelian produk dibandingkan dengan perusahaan lain (Lupiyoadi, 2016:143). Nilai pelanggan berkonstribusi terhadap kepuasan pelanggan yang dapat menciptakan loyalitas pelanggan (Sugiati et al, 2013). Serta nilai emosional, nilai sosial dan nilai kualitas berpengaruh terhadap kepuasan pelanggan (Ridwan dan Palupinindyah, 2014). Nilai positif secara langsung mempengaruhi kepuasan pelanggan dan dianggap sebagai respon yang efektif atas layanan yang diberikan (Moh. Nazri, Raji, \& Zainal, 2016). Nilai pelanggan adalah nilai yang dapat memuaskan pelanggan (Sugiati, Thoyib, Hadiwidjoyo, \& Setiawan, 2013). Tujuan penciptaan nilai pelanggan adalah untuk menciptakan kepuasan pelanggan (Indra Permana Kusuma Putra, et al. 2020). Nilai pelanggan dapat membentuk kepuasan pelanggan (Logiawan \& Subagio, 2014). Kepuasan pelanggan adalah hasil nilai pelanggan dan kepercayaan, komitmen dari mulut ke mulut (Mbango, 2019). Salah satu tugas terpenting dalam pemasaran adalah menciptakan dan mengkomunikasikan customer value kepada konsumen untuk mendorong kepuasan dan kesetiaan pelanggan (Burhan, Mansur, \& Immawan, 2020). Berdasarkan penjelasan di atas, dapat disimpulkan bahwa nilai pelanggan berkaitan dengan kepuasan pelanggan.

\section{METODE}

Metode penelitian yang digunakan dalam penelitian ini adalah metode deskriptif verifikatif, yaitu metode untuk menjelaskan hubungan yang bersifat kausalitas nilai pelanggan yang didukung oleh dimensi product value, service value, personal value, image value, dan cost value (Kotler dan Keller, 2009) dengan kepuasan pelanggan yang didukung oleh overall satisfaction, confirm to expectation, dan comparison to ideal (Fornell et all, 1996). Data penelitian yang digunakan dalam penelitian ini adalah data kuantitatif yaitu data yang dapat diukur berupa informasi yang dinyatakan dengan bilangan atau berbentuk angka-angka dan data kualitatif yaitu data yang disajikan bukan dalam bentuk angka. Sumber data penelitian diambil dari data primer yaitu data yang langsung dikumpulkan dari sumber partama yaitu pengunjung dan sumber data sekunder yaitu data yang langsung dikumpulkan sebagai data penunjang dari sumber data utama.

Pengumpulan data dilakukan melalui angket yaitu daftar pertanyaan yang memiliki jawaban sangat setuju dengan kategori nilai lima sampai sangat tidak setuju dengan kategori nilai satu, selanjutnya diberikan kepada responden untuk diisi. Adapun jumlah daftar pertanyaan yang dimaksud didasarkan atas banyaknya jumlah pertanyaan dari masing-masing indikator, yaitu enam pertanyaan pada product value, tiga pertanyaan pada service value, empat pertanyaan pada personal value, tiga pertanyaan pada image value, dan empat pertanyaan pada cost value. Sementara jumlah daftar pertanyaan pada variabel kepuasan pengunjung, terdiri dari lima pertanyaan.

Wawancara dilakukan kepada pengunjung dan karyawan Saung Angklung Udjo dengan tujuan mendapatkan data tambahan guna melengkapi data sebelumnya yang diambil melalui angket.

Teknik analisis data dilakukan dengan menggunakan analisis regresi linier berganda 
untuk melihat perubahan variabel nilai pengunjung yang didukung oleh lima indikator pendukungnya, yaitu product value, service value, personal value, image value, dan cost value sebagai variable eksogenus. Kelima indikator pendukung variabel nilai pengunjung ini menjadi faktor penentu perubahan pada variable kepuasan pengunjung. Variabel nilai pengunjung menggunakan teori nilai pelanggan yang digunakan oleh Kotler dan Keller (2009). Variabel kepuasan pengunjung menggunakan teori yang disampaikan oleh Fornell et all (1996), yang menjelaskan bahwa terdapat tiga indikator pendukung variabel kepuasan pelanggan yang dalam penelitian ini selanjutnya disebut kepuasan pengunjung, yaitu overall satisfaction, confirm to expectation dan comparison to ideal. Pembahasan terhadap hasil penelitian ini dilanjutkan dengan memberikan makna tentang pentingnya nilai pengunjung yang dapat menentukan kepuasan pengunjung di destinasi wisata Saung Angklung Udjo. Fenomena tersebut menjadi tema dalam penelitian ini sehingga melahirkan judul penelitian Nilai Kepuasan Pengunjung Saung Angklung Udjo.

\section{HASIL DAN PEMBAHASAN}

\section{Hasil Analisis Statistika}

Hasil analisis statistika terhadap variabel penelitian tentang nilai pelanggan sebagai faktor penentu kepuasan pelanggan, dapat disampaikan sebagai berikut ini.

Tabel 1. Hubungan Nilai Pelanggan dengan Kepuasan

\begin{tabular}{llrr}
\hline & & Satisfaction & Customer Value \\
\hline \multirow{2}{*}{ Pearson Correlation } & Satisfaction & 1.000 & .726 \\
& Customer Value & .726 & 1.000 \\
\multirow{2}{*}{ Sig. (1-tailed) } & $\mathrm{Y}$ & & .000 \\
& $\mathrm{n}$ &. & \\
$\mathrm{N}$ & $\mathrm{X}$ & .000 &. \\
& $\mathrm{Y}$ & 200 & 200 \\
& $\mathrm{X}$ & 200 & 200 \\
\hline
\end{tabular}

Hasil analisis statistika mengenai hubungan nilai pelanggan dengan kepuasan pelanggan, diperoleh hasil perhitungan 0.726 yang menjelaskan bahwa hubungan tersebut KUAT. Nilai P-Value diperoleh sebesar 0.000 , lebih kecil dari nilai alpha 0.05, artinya bahwa hubungan variabel nilai pelanggan dengan kepuasan pelanggan Signifikan. Hubungan kedua variabel ini menjelaskan bahwa tingginya tingkat kepuasan pelanggan dalam seni pertunjukan Saung Angklung Udjo, sangat berhubungan dengan tingginya tingkat nilai pelanggan. Lebih jelas dapat disampaikan bahwa semakin tinggi tingkat nilai pelanggan yang diberikan oleh pihak pengelola, maka semakin tinggi pula peluang bagi pelanggan untuk mendapatkan kepuasannya. Atau sebaliknya. Semakin rendah tingkat nilai pelanggan yang diberikan oleh pihak pengelola, maka semakin rendah pula peluang bagi pelanggan untuk mendapatkan kepuasannya. Ini berarti nilai pelanggan sangat berarti bagi perubahan peningkatan kepuasan pelanggan.

Sementara hasil analisis regresi linier sederhana untuk melihat perubahan pada variabel kepuasan pelanggan sebagai akibat dari perubahan nilai pelanggan, disampaikan berikut ini 
Tabel 2. Hasil Analisis Regresi Linier

\begin{tabular}{llrrrrrr}
\hline Model & & \multicolumn{2}{c}{$\begin{array}{c}\text { Unstandardized } \\
\text { Coefficients }\end{array}$} & $\begin{array}{c}\text { Standardized } \\
\text { Coefficients } \\
\text { Beta }\end{array}$ & t & & Sig. \\
& & \multicolumn{1}{c}{ B } & Std. Error & \multicolumn{1}{c}{ Beta } & \\
\hline \multirow{2}{*}{1} & (Constant) & 1.109 & 1.074 & & 1.033 & .303 \\
& $\mathrm{X}$ & .238 & .016 & & .726 & 14.853 & .000 \\
\hline
\end{tabular}

a. Dependent Variable: Customer Satisfaction

Hasil analisis regresi pada variabel nilai pelanggan dengan variabel kepuasan pelanggan diperoleh hasil 1.109 dengan 0.238 , sehingga mendapatkan persamaan $\mathrm{Y}=$ $1.109+0.238 \mathrm{X}$. Persamaan tersebut menjelaskan bahwa peningkatan kepuasan yang dirasakan pelanggan selama melakukan kunjungan untuk menyaksikan pentas angklung di Saung Angklung Udjo adalah 1.109, ketika tidak adanya nilai pelanggan. Peningkatan kepuasan pengunjung sebesar 0.238 , bila terdapat peningkatan sebesar satu satuan pada nilai pelanggan. Hal ini menjelaskan bahwa nilai pelanggan menjadi faktor penentu kenaikan kepuasan pelanggan selama menyaksikan pentas Seni Pertunjukan Saung Angklung Udjo. Lebih jauh dapat disampaikan bahwa nilai pelanggan merupakan faktor penentu dalam perubahan peningkatan kepuasan pelanggan, sehingga nilai pelanggan memiliki nilai yang sangat berarti dalam pencapaian kepuasan maksimal bagi pelanggannya.

Hasil analisis $R$ Square digunakan untuk melihat koefisien determinasi, besarnya nilai penentu perubahan pada kepuasan pelanggan karena perubahan pada nilai pelanggan, sebagai berikut.

Tabel 3. Hasil Analisis $R$ Square

\begin{tabular}{|c|c|c|c|c|c|c|}
\hline \multirow[t]{2}{*}{ Model } & \multirow[t]{2}{*}{$\mathbf{R}$} & \multirow{2}{*}{$\begin{array}{c}\text { R } \\
\text { Square }\end{array}$} & \multirow{2}{*}{$\begin{array}{l}\text { Adjusted R } \\
\text { Square }\end{array}$} & \multirow{2}{*}{$\begin{array}{l}\text { Std. Error of } \\
\text { the Estimate }\end{array}$} & \multicolumn{2}{|c|}{ Change Statistics } \\
\hline & & & & & $\begin{array}{c}\text { R } \\
\text { Square } \\
\text { Change }\end{array}$ & F Change \\
\hline 1 & $.726^{\mathrm{a}}$ & .527 & .525 & 2.02983 & .527 & 220.599 \\
\hline
\end{tabular}

Hasil analisis $R$ Square menunjukkan koefisien korelasi sebesar 0.726, yang menjelaskan hubungan nilai pelanggan dengan kepuasan pelanggan. Sementara koefisien $R$ Square sebesar 0.527 yang menggambarkan nilai koefisien determinasi ketika nilai tersebut dikalikan dengan 100 persen, sehingga menghasilkan angka 52.7 persen. Nilai 52.7 persen ini merupakan nilai koefisien determinasi atau besarnya pengaruh variabel nilai pelanggan terhadap variabel kepuasan pelanggan. Sementara sisanya sebesar 47.3 persen, variabel kepuasan pelanggan dipengaruhi oleh faktor lain yang tidak diteliti. Tingginya tingkat pengaruh nilai pelanggan terhadap kepuasan pelanggan yang mencapai 52.7 persen, memberikan penjelasan bahwa dalam konteks penelitian ini, nilai pelanggan menjadi faktor penentu yang paling besar dibandingkan dengan faktor-faktor penentu lainnya seperti harga, kualitas pelayanan, citra merek, citra organisasi, dan lainnya yang tidak diteliti.

\section{Seni Pertunjukan Saung Angklung Udjo}

Saung Angklung Udjo merupakan perpaduan nama yang memberikan makna dari nama tempat, nama orang serta nama alat pertunjukan kesenian. Tempat berupa saung adalah tempat untuk pentas kesenian angklung di bawah kendali pengelolaan Bapak Udjo. Saung Angklung Udjo merupakan satu destinasi yang memiliki daya tarik wisata pada aspek seni pertunjukan yang bernilai Budaya Sunda. Seni pertunjukan Saung Angklung Udjo merupakan pertunjukan seni tradisional dengan angklung sebagai alat musik 
pengiringnya. Seni pertunjukan angklung ini diiringi oleh alunan angklung yang dipadukan dengan lantunan lagu-lagu yang berbahasa Sunda, namun di dalam perkembangannya, lantunan lagu tersebut, berkembang menjadi lagu-lagu popular kekinian, bahkan lagu-lagu Barat. Pengiringnya terdiri dari para pemain dengan peran masing-masing yang bertugas sesuai dengan perannya, saling melengkapi dalam bunyi sehingga menghasilkan suara yang indah. Keindahan inilah memberikan nilai bagi para penontonnya dan dapat menggambarkan nilai pemainnya.

\section{Nilai Pelanggan}

Pengunjung menunjukkan rasa senang atas sajian paket pertunjukan yang disuguhkan. Paket pertunjukan ini diawali dengan sajian lagu-lagu daerah Sunda, lagu nasional sampai pada lagu Barat. Angklung yang berbasis budaya lokal Jawa Barat dapat mengiringi setiap lagu dengan penuh kekhusuan. Hal ini ditunjang oleh penampilan para penari dan pemain musik dengan motif dan warna seragam pakaian yang dikenakannya menunjukkan hal yang beda. Penampilan mereka memberikan nilai keserasian dalam penampilan. Aspek lain yang juga memberikan nilai lebih kepada pengunjung adalah kebersihan tempat pertunjukan yang membuatnya betah selama pertunjukan. Paket pertunjukan dengan segala nilai yang ditunjukannya berdampak pada tumbuhnya ingatan kepada seluruh pengunjung tentang penampilan seni pertunjukan Saung Angklung Udjo.

Nilai Jasa. Pelayanan kepada pengunjung dalam bentuk kecepatan dan ketepatan selama persiapan masuk pertunjukan sampai berakhirnya pertunjukan baik yang bersifat intangible maupun yang bersifat tangible, telah memberikan kepuasan kepada para pengunjungnya. Hal ini sesuai dengan prinsip yang diberlakukan oleh pengelola Saung Angklung Udjo bahwa pelayanan merupakan aspek yang sangat penting dan sangat menentukan dalam upaya meningkatkan kepuasan pelanggan, sehingga bisa melakukan kunjungan ulang. Pentingnya aspek nilai pelayanan dalam organisasi bisnis termasuk destinasi pariwisata menguatkan pendapat yang disampaikan oleh Nazri et al., (2016) bahwa nilai positif secara langsung mempengaruhi kepuasan pelanggan dan dianggap sebagai respon yang sangat efektif atas pelayanan yang diberikan. Hal yang sama disampaikan oleh Donny et al., (2018) bahwa pelanggan adalah investasi jangka panjang bagi perusahaan, sehingga perusahaan harus dapat memberikan pelayanan terbaik kepada pelanggan untuk keberlangsungan bisnisnya melalui penciptaan nilai pelanggan. Sementara Supriyadi et al., (2020) menyatakan bahwa konsumen menuntut nilai yang lebih tinggi dibandingkan dengan harga tinggi konsumen dapat membedakan harga dan nilai yang dibelanjakan dengan layanan yang diterima.

Nilai Personal. Karyawan garis depan yang tugasnya memberikan layanan kepada pengunjung baik dalam bentuk layanan tiket, layanan informasi pertunjukan, layanan bimbingan pengunjung selama menyaksikan pertunjukan, telah dirasakan memberikan kesenangan yang maksimal bagi pengunjungnya. Hal yang dilihat adalah dari aspek komunikasi karyawan baik kejelasan pesan yang disampaikan maupun cara berkomunikasi; juga pada aspek ketelitian saat memberikan petunjuk dalam memainkan angklung bagi para pengunjung, yang dibarengi dengan keramahan dan kesopanan, sehingga membuat para pengunjung merasa mendapatkan penghargaan dan merasa betah selama menyaksikan pertunjukan.

Nilai Citra. Tingginya nilai pertunjukan yang dirasakan pengunjung, dengan nilai pelayanan yang maksimal selama pertunjukan berlangsung, dibarengi dengan nilai personal berdampak pada tumbuhnya citra positif dari para pengunjungnya terhadap Saung Angklung Udjo. Hal ini berdampak pada tumbuhnya kebanggaan para pengunjung ditambah dengan akses masuk yang mudah dijangkau. Hal lain adalah Saung Angklung Udjo, telah mendapatkan tempat di hati para pengunjung 
baik di Jawa Barat, Indonesia bahkan di Manca Negara. Artinya Saung Angklung Udjo merupakan destinasi wisata dengan atraksi wisata yang sangat terkenal.

Nilai Biaya. Tingginya tingkat manfaat yang dirasakan pengunjung melalui perbandingan antara nilai uang yang dikeluarkan, kecepatan pelayanan yang dirasakan, tempat untuk menyaksikan pertunjukan, serta seluruh pelayanan yang diberikan karyawan dalam pertunjukan Angklung Udjo, berdampak pada perasaan senang yang maksimal dari para pengunjung.

Tingginya nilai pelanggan yang digambarkan melalui tingginya nilai pertunjukan, nilai pelayanan, nilai personal, nilai citra, dan nilai biaya selama menyaksikan seni pertunjukan Saung Angklung Udjo menunjukkan tingkat kesesuaian dengan pendapat yang disampaikan oleh (Kotler dan Keller, 2009) yang menyatakan bahwa nilai pelanggan dibangun oleh dimensi-dimensinya yaitu nilai produk, nilai pelayanan, nilai personal, nilai citra dan nilai biaya. Kelima dimensi pendukung ini menjadi bagian penting dalam membangun nilai pelanggan dalam sebuah organisasi. Apa yang disampaikan Kotler dan Keller (2009) terkait lima faktor pendukung nilai pelanggan memiliki kesesuaian dengan pendapat yang disampaikan oleh Tjiptono, (2014) bahwa nilai pelanggan dapat diukur dengan menggunakan emotional value, social value, performance value dan value of money. Apa yang disampaikan Kotler dan Keller, (2009) serta Tjiptono, (2014) tentang pentingnya nilai pelanggan dengan faktorfaktor pendukungnya, karena dapat menentukan kepuasan pelanggan. Hal ini sejalan dengan pendapat yang disampaikan oleh Permana, Putra, Hudayah, \& Achmad, (2020) bahwa tujuan pentiptaan nilai pelanggan adalah untuk menciptakan kepuasan pelanggan, semakin tinggi nilai pelanggan, maka semakin tinggi kepuasan yang dirasakan pelanggan. Juga disampaikan oleh Galih Saputra \& Juju, (2020) bahwa pemberian nilai yang unggul kepada pelanggan merupakan sebuah tugas pokok perusahaan pada dasar yang kompetitif, karena nilai pelanggan yang lebih tinggi dapat meningkatkan kepuasan pelanggan. Hal yang sama disampaikan oleh Mbango, (2019) bahwa kepuasan pelanggan adalah sebuah hasil dari nilai pelanggan dan kepercayaan, komitmen dari mulut ke mulut dan loyalitas adalah konsekuensi dari kepuasan pelanggan.

\section{Kepuasan Pengunjung}

Kepuasan pengunjung selama menyaksikan pertunjukan Angklung Udjo baik pada aspek nilai seni, nilai pelayanan, nilai personal, nilai citra, serta nilai biaya yang dikeluarkan menunjukkan tingkat kepuasan yang tinggi. Hal ini terjadi karena seni pertunjukan Angklung di Saung Angklung Udjo telah sesuai bahkan melebihi harapan pengunjung. Tingginya tingkat kepuasan pengunjung ini sejalan dengan pendapat yang disampaikan oleh Kotler dan Keller (2009:139) bahwa perasaan senang atau kecewa yang dirasakan oleh seseorang sebagai akibat dari perbandingan antara kinerja produk dan pelayanan dengan harapannya. Hal yang sama disampaikan oleh Gasperz (2011:38) bahwa kepuasan pelanggan merupakan suatu keadaan dimana kebutuhan dan harapan pelanggan terpenuhi melalui produk yang dikonsumsi. Sementara Fornell et all (1996) menjelaskan lebih rinci bahwa kepuasan yang dirasakan pengunjung ini sebagai dampak dari pengalaman terakhir setelah menyaksikan seni pertunjukan Angklung Udjo, tingginya tingkat kesesuaian antara harapan pengunjung dan apa yang dirasakan terutama pada aspek pelayanan serta pertunjukan Angklung. Saputra \& Juju, (2020) lebih menitikberatkan pada aspek penentu kepuasan pelanggan dengan mengatakan bahwa upaya untuk dapat memberikan kepuasan kepada pelanggan adalah bagaimana memberikan nilai kepada pelanggan. Pemberian nilai yang unggul kepada pelanggan yang lebih tinggi dapat meningkatkan kepuasan pelanggan. Hal yang sama disampaikan oleh Tsai et al., (2010) bahwa belanja pelanggan dilakukan atas dasar nilai yang diharapkan karena akan berdampak pada kepuasan dan loyalitas 
pelanggan, sehingga berpottensi melakukan pembelian ulang. Juga disampaikan oleh Wahyuningsih, (2005) bahwa memberikan nilai yang luar biasa kepada pelanggan merupakan satu-satunya cara yang dapat diandalkan untuk mencapai kepuasan pelanggan berkelanjutan.

Atas dasar hasil pembahasan seperti disampaikan dalam sub judul kepuasan pengunjung maka dapat disampaikan bahwa kepuasan pengunjung merupakan faktor yang sangat penting dalam sebuah organisasi bisnis termasuk destinasi pariwisata. Pentingnya faktor kepuasan pengunjung ini akan berdampak pada tumbuhnya loyalitas pengunjung, sehingga berdampak pada keberlanjutan usaha destinasi melalui kunjungan ulang pengunjung kepada destinasi.

\section{Nilai Pelanggan sebagai Faktor Penentu Kepuasan}

Kegiatan Seni Pertunjukan Saung Angklung Udjo merupakan kegiatan seni pertunjukan yang sarat dengan nilai. Nilai yang terkandung di dalamnya adalah nilai yang dirasakan oleh seluruh pengunjung yang menyaksikan pertunjukan. Pengunjung mendapatkan rasa senang atas paket seni pertunjukan, penampilan penari dengan motif pakaian yang dikenakan sehingga memberikan keserasian dalam penampilan, ditunjang kebersihan tempat yang berdampak pada tumbuhnya ingatan bagi para pengunjung akan seni pertunjukan Angklung Udjo. Pengunjung juga mendapatkan rasa senang atas ketepatan dan kecepatan dalam pelayanan, kemampuan komunikasi, ketelitian, kesopanan dan keramahan serta tingkat efisiensi atas dana yang digunakan. Akhirnya pengunjung mendapatkan rasa bangga baik atas pertunjukan yang telah disaksikannya, atas citra Saung Angklung Udjo, serta lokasi yang relatif mudah dijangkau.

Tingginya nilai pengunjung yang dibangun oleh nilai pertunjukan, pelayanan, personal, citra maupun nilai biaya menjadi faktor penentu tumbuhnya kepuasan pengunjung.
Semakin tinggi nilai yang diterima pengunjung melalui lima komponen pembentuknya, maka semakin tinggi pula tingkat kepuasan pengunjung atau sebaliknya, semakin rendah nilai yang diterima pengunjung melalui komponen pembentuknya, maka semakin rendah kepuasan yang akan dirasakan pengunjung. Penjelasan ini sejalan dengan pendapat yang disampaikan oleh (Lupiyoadi, 2016:143) bahwa faktor penentu tingkat kepuasan seorang pelanggan adalah dari nilai lebih yang terdapat pada suatu produk maupun kinerja pelayanan yang diterima dari suatu proses pembelian terhadap produk.

Hal yang sama disampaikan oleh Sugiati et all (2013) bahwa nilai pelanggan berkontribusi terhadap kepuasan pelanggan yang pada gilirannya menciptakan loyalitas pelanggan. Juga disampaikan Ridwan dan Palupinindyah (2014) bahwa nilai emosional, nilai sosial dan nilai kualitas berpengaruh positif dan signifikan terhadap kepuasan pelanggan. Sementara Nazri et al., (2016) memberikan pendapat dengan menggunakan istilah nilai positif bahwa nilai positif secara langsung mempengaruhi kepuasan pelanggan dan dianggap sebagai respon yang efektif atas layanan yang diberikan. Sugiati et al., (2013) secara tegas menjelaskan bahwa Nilai pelanggan adalah nilai yang dapat memuaskan pelanggan dan menjadikannya pelanggan setia.

Hal yang sama disampaikan oleh Logiawan \& Subagio, (2014) bahwa nilai pelangan merupakan sesuatu yang sangat berperan dalam membentuk kepuasan pelanggan. Sedikit berbeda dengan pendapat yang disampaikan oleh Permana et al., (2020) bahwa tujuan penciptaan nilai adalah untuk menciptakan kepuasan pelanggan, nilai pelanggan sebagai faktor utama dalam menawarkan produk, sehingga semakin tinggi nilai pelanggan, maka semakin tinggi kepuasan pelanggan. Lebih jauh dijelaskan oleh Mbango, (2019) bahwa kepuasan pelanggan adalah sebuah hasil dari nilai pelanggan dan kepercayaan, komitmen dari mulut ke mulut dan loyalitas adalah 
konsekuensi dari kepuasan pelanggan. Juga disampaikan oleh Burhan et al., (2020) bahwa salah satu tugas terpenting dalam pemasaran adalah menciptakan dan mengkomunikasikan customer value kepada konsumen untuk mendorong kepuasan dan kesetiaan pelanggan.

Atas dasar hasil penelitian sebelumnya dibandingkan dengan hasil penelitian ini, maka dapat disampaikan bahwa nilai pelanggan yang didukung oleh product value, service value, personal value, image value, dan cost of value merupakan aspek yang sangat penting dalam dunia bisnis, karena menjadi faktor penentu perubahan pada kepuasan pelanggan baik pada aspek overall satisfaction, confirm to expectation, dan comparison to ideal. Tingginya tingkat signifikansi tentang pentingnya nilai pelanggan dalam dunia bisnis harus menjadi fokus perusahaan dalam pencapaian kepuasan pelanggan. Semakin tinggi tingkat nilai pelanggan maka semakin tinggi pula peluang bagi perusahaan untuk dapat memberikan kepuasan kepada pelanggannya. Atau sebaliknya. Semakin rendah tingkat nilai pelanggan, maka semakin rendah pula tingkat peluang bagi perusahaan untuk dapat memberikan kepuasan kepada pelanggannya.

\section{Nilai Kepuasan Pengunjung Saung Angklung Udjo}

Kegiatan kunjungan wisatawan untuk menyaksikan pentas seni angklung, merupakan satu kegiatan yang berdampak pada tumbuhnya kepuasan pengunjung. Kepuasan pengunjung merupakan kumpulan perasaan, hasil perbandingan dari yang diharapkan dengan yang dirasakan pada aspek seni pertunjukan, pelayanan, nilai personal, nilai citra dan nilai biaya. Perasaan puas pengunjung sebagai wujud dari ketercapaian harapan pengunjung yang dapat memberikan manfaat bagi masyarakat, seperti meningkatnya pengetahuan, tumbuhhnya rasa senang, dan kembalinya rasa segar untuk beraktivitas harian. Hal ini dapat diyakini sebagai model dalam proses penyegaran kembali, ketika masyarakat mendapatkan rasa jenuh dalam aktivitas rutinnya. Kepuasan merupakan aspek penting dalam masyarakat yang dapat dijadikan acuan dalam proses interaksi serta sebagai sebuah pola tingkah laku dan pola fikir kelompok yang diakui masyarakat dalam berwisata. Atas dasar kepuasan merupakan perasaan senang atau kecewa yang timbul dari seseorang karena membandingkan kinerja yang dipersepsikan produk terhadap ekspektasi pelanggan, sehingga kepuasan pelanggan merupakan suatu keadaan dimana kebutuhan dan harapan pelanggan terpenuhi melalui produk yang dikonsumsi sehingga kepuasan dan ketidakpuasan merupakan perbandingan antara harapan pelanggan dan kenyataan dari kualitas produk dan pelayanan yang dirasakan oleh pelanggan. Pengunjung dengan sendirinya telah membandingkan dari apa yang telah dirasakannya baik atas dasar pelayanan maupun atas dasar pertunjukan yang dilihatnya. Sebagian besar pengunjung telah merasakan kepuasan atas pelayanan dan pertunjukan dan mereka menunjukkan kesiapannya untuk memberikan rekomendasi kepada orang lain tentang Saung Angklung Udjo yang memiliki keunggulan dalam pertunjukan dan memiliki kelayakan untuk ditonton. Kepuasan pengunjung sebagai dampak dari tumbuhnya nilai pengunjung dalam konteks kunjungan untuk menyaksikan pentas seni pertunjukan Saung Angklung Udjo, sehingga menjadi "Nilai Kepuasan Pengunjung Saung Angklung Udjo".

\section{SIMPULAN}

Seni pertunjukan Saung Angklung Udjo merupakan pertunjukan seni tradisional angklung khas Jawa Barat yang memadukan gamelan dengan angklung yang berbahan dasar bambu sebagai pengiring lagu. Iringan pertunjukan angklung, menghasilkan alunan nada yang indah menumbuhkan rasa senang dan rasa puas bagi penontonnya, sebagai dampak dari tumbuhnya nilai penampilan penari dan pemain musik dengan motif pakaian yang serasi, kebersihan tempat pertunjukan, kecepatan dan ketepatan pelayanan, kemampuan komunikasi, 
ketelitian, kesopanan dan keramahan pelayan, citra merek dengan tempat yang mudah dijangkau. Nilai uang, waktu, energi dan fisik yang efisien sehingga mendapatkan nilai manfaat yang maksimal.

Tumbuhnya perasaan puas pengunjung sebagai wujud dari ketercapaian harapan pengunjung yang dapat memberikan pengetahuan, rasa senang dan kembalinya rasa segar untuk beraktivitas harian, yang menjadi model dalam proses refreshing masyarakat dari rasa jenuh. Ini merupakan aspek penting dalam masyarakat yang dapat dijadikan acuan dalam proses interaksi serta sebagai pola tingkah laku dan pola fikir kelompok yang diakui bersama dalam masyarakat. Aspek penting kepuasan pengunjung sebagai dampak dari tumbuhnya nilai pengunjung dalam konteks kunjungan untuk menyaksikan pentas seni pertunjukan Saung Angklung Udjo.

Nilai pelanggan menjadi aspek penting baik dalam organisasi bisnis maupun dalam dunia akademis yang dalam konteks penelitian ini menjadi nilai pengunjung. Atas dasar hal tersebut maka saran yang bisa disampaikan:

Saran praktis dalam organisasi bisnis Saung Angklung Udjo dapat menjadikan nilai pengunjung menjadi hal penting yang harus diperhatikan sehingga dapat dibuat kebijakan bagaimana meningkatkan nilai pengunjung, karena menjadi aspek yang sangat mendasar dalam peningkatan kepuasan pengunjung;

Saran akademis dapat dilakukan penelitian lebih mendalam tentang nilai pengunjung baik sebagai faktor penentu perubahan pada variabel dependen maupun sebagai variabel dependen dengan mencari variabel-variabel lain yang menjadi faktor perubahan nilai pengunjung.

\section{DAFTAR PUSTAKA}

Amstrong, P. K. and. (2008). Manajemen Pemasaran. Jakarta: PT Indeks.

Burhan, G. F., Mansur, A., \& Immawan, T. (2020). Perencanaan Strategi Pemasaran
Berdasarkan Customer Value, 4(2), 2940.

Donny, J. R., Juju, U., Jusuf, E., \& Rosmadi, M. L. N. (2018). The Factors That Affect Customer Value and Its Impact on the Customer Loyalty. Budapest International Research and Critics Institute (BIRCI-Journal): Humanities and Social Sciences, 1(4), 299-305. https://doi.org/10.33258/birci.v1i4.122

Fornell C. Johnson, MD, A. E. (1996). The American Customer Satisfaction Index: Nature, Purpose and Findings. Journal of Marketing, 60.

Gasperz, V. (2011). Lean Six Sigma for Manufacturing and Service Industries. Jurnal sains pemasaran indonesia. Bogor: Penerbit Vinchristo Publication

Halimatussakdiah, M. T. dan I. S. (2009). Customer Perceived Value, Satisfaction and Trust Toward Islamic Bank: A Conceptual Framework. AGC-Best, 2(1988), 93-97.

Kotler, K. dan. (2009). Marketing

Management (Thirteen E). New Jersey: Prentice Hall.

Kotler, K. L. dan P. (2009). Marketing Management (Thirteen E). New Jersey: Prentice Hall.

Logiawan, Y., \& Subagio, H. (2014). Analisa Customer Value Terhadap Customer Loyalty Dengan Customer Satisfaction Sebagai Variabel Intervening Pada Restoran Bandar Djakarta Surabaya. Manajemen Pemasaran, 2(1), 1-11.

Lupiyoadi, R. (2011). Manajemen

Pemasaran Jasa (Edisi Kedu). Jakarta: Salemba Empat.

Lupiyoadi, R. (2016). Manajemen Pemasaran Jasa Berbasis Kompetensi. Jakarta: Penerbit Salemba Empat. 
Mbango, P. (2019). The role of perceived value in promoting customer satisfaction: Antecedents and consequences. Cogent Social Sciences, $5(1)$. https://doi.org/10.1080/23311886.2019. $\underline{1684229}$

Nazri, M., Raji, A., \& Zainal, A. (2016). The effect of customer perceived value on customer satisfaction: A case study of Malay upscale restaurants. Geografia Malaysian Journal of Society and Space, 12(3), 58-68.

Nursyirwan, V. I., Valentika, N., (2020). ..., and Perceived Value on Satisfaction Level and Loyalty of E-Commerce Customer. Case Study on E-Commerce Customer of Shopee. Proceedings. Retrieved from http://openjournal.unpam.ac.id/index.ph p/PISA/article/view/8809

Palupinindyah, R. (2014). Pengaruh Nilai Emosional, Nilai Sosial dan Nilai Kualitas Terhadap Kepuasan Pelanggan.

Permana, I., Putra, K., Hudayah, S., \& Achmad, G. N. (2020). 3 1,2,3, 2020 (2), 151-160.

Rangkuti, F. (2006). Teknik Mengukur dan Strategi Meningkatkan Kepuasan Pelanggan. Jakarta: Penerbit PT Gramedia Pustaka Utama.

Sambinelli, F., \& Francisco Borges, M. A. (2019). Survey on strategies to increase customer value in Brazilian Agile software development companies. Iberian Conference on Information Systems and Technologies, CISTI, 2019June(2). https://doi.org/10.23919/CISTI.2019.87 60653

Saputra, G. G., \& Juju, U. (2020). Service Delivery Terhadap Customer Value
Serta Dampaknya Pada Kepuasan Pelanggan. Journal.Unpas.Ac.Id, 13(2), 52-60. Retrieved from http://www.journal.unpas.ac.id/index.ph $\mathrm{p} / \mathrm{jrbm} / \mathrm{article} / \mathrm{view} / 3006$

Sugiati, T. et all. (2013). The Role of Customer Value on Satisfaction and Royalty (Study on Hypermart's Customers)". International Journal of Business and Management Invention ISSN (Online 2), (6) 2319-8.

Sugiati, T., Thoyib, A., Hadiwidjoyo, D., \& Setiawan, M. (2013). The Role of Customer Value on Satisfaction and Loyalty (Study on Hypermart's Customers). International Journal of Business and Management Invention ISSN (Online, 2(6), 65-70.

Supriyadi, S., Hertanto, H., \& Rafiq, M. (2020). Customer Value Toward Purchase Intention on Luxury Brand. Business and Entrepreneurial Review, 20(1), 33.

https://doi.org/10.25105/ber.v20i1.6781

Syarifuddin, D. (2012). Increasing Number of Tourists by means of Tourist Value.

Syarifuddin, D. (2016). Nilai Budaya Batik Tasik Parahiyangan Sebagai Daya Tarik Wisata Jawa Barat, 14(2), 9-20. https://doi.org/10.17509/jurel.v14i2.853 0

Syarifuddin, D. (20117). Nilai Wisata Budaya Seni Pertunjukan Saung Angklung Udjo Kota Bandung, Jawa Barat, Indonesia. Jurnal Manajemen Resort and Leisure, 13(2), 53-60. https://doi.org/10.17509/jurel.v13i2.497 9

Syarifuddin, D. (2018). Nilai Citra Kota Dari Sudut Pandang Wisatawan (Studi Tentang Citra Kota Bandung Dampaknya Terhadap Kunjungan Ulang) Didin Syarifuddin. 
Tjiptono, F. (2014). Pemasaran Jasa. Yogyakarta: Andi.

Tran, V. D., \& Le, N. M. T. (2020). Impact of service quality and perceived value on customer satisfaction and behavioral intentions: Evidence from convenience stores in Vietnam. Journal of Asian Finance, Economics and Business, 7(9), 517-526. https://doi.org/10.13106/JAFEB.2020.V OL7.NO9.517

Tsai, M. T., Tsai, C. L., \& Chang, H. C. (2010). The effect of customer value, customer satisfaction, and switching costs on customer loyalty: An empirical study of hypermarkets in Taiwan. Social Behavior and Personality, 38(6), 729740. https://doi.org/10.2224/sbp.2010.38.6.7 $\underline{29}$

Wahyuningsih, W. (2005). The Relationships among Customer Value, Satisfaction and Behavioral Intentions: A General Structural Equation Model. Gadjah Mada International Journal of Business, 7(3), 301. https://doi.org/10.22146/gamaijb.5584

Yulisetiarini, D., \& Prahasta, Y. A. (2019). The effect of price, service quality, customer value, and brand image on customers satisfaction of telkomsel cellular operators in east Java Indonesia. International Journal of Scientific and Technology Research, 8(3), 5-9.

Zeithaml, V. A. (1988). Customer Perceptions of Price, Quality and Value : A Means-End Model and Synthesis of Evidence. Journal of Marketing, 52. 